\title{
Total Skin Electron Beam Therapy as Part of Multimodal Treatment Strategies for Primary Cutaneous T-Cell Lymphoma
}

\author{
Khaled Elsayad Katharina H. Susek Hans T. Eich \\ Department of Radiation Oncology, University Hospital of Muenster, Muenster, Germany
}

\section{Keywords \\ Radiotherapy - Total skin electron beam therapy . Mycosis fungoides · Sézary syndrome - Skin-directed . Systemic therapy $\cdot$ Immunotherapy}

\section{Summary}

Total-skin electron beam therapy (TSEBT) is one of most effective treatments that has been used for cutaneous $T$ cell lymphoma. Low-dose TSEBT regimens (10-12 Gy) appear to be an effective alternative to conventionaldose TSEBT (30-36 Gy), yielding short-term remission of cutaneous manifestations with minimal toxicity. TSEBT can be administered to patients any time after a diagnosis of mycosis fungoides (MF). Patients requiring rapid relief from cutaneous lesions or symptoms may particularly benefit from TSEBT as an initial therapy. Radiotherapy (RT) dose, boost radiation delivery, maintenance treatment, and radiation tolerability may enhance remission rates and improve relapse-free survival following TSEBT. In addition, salvage local RT or TSEBT may be safely applied with high effectiveness. In this review, we focus on the use of TSEBT in patients with several forms of primary cutaneous T-cell lymphoma, and highlight the potential of low-dose TSEBT as part of a promising therapeutic approach.

(C) 2017 S. Karger GmbH, Freiburg

\section{Introduction}

Primary cutaneous T-cell lymphoma (pCTCL) is a heterogeneous group of non-Hodgkin's lymphomas that represents more than two thirds of cutaneous lymphomas with an incidence of approximately 0.77 per 100,000 person-years at diagnosis [1]. Although a variety of mechanisms, genetic factors, and signaling pathway dysregulations have been reported in association with PCTCL, the etiology of PCTCL is still unclear [2]. Histopathologically, cutaneous manifestations of PCTCL are characterized by clonal proliferation of skin-homing malignant $\mathrm{T}$ lymphocytes and natural killer cells [3]. Severity of pCTCL has been determined with molecular diagnostic studies, immunohistochemistry, and flow cytometry, in addition to characteristic genetic features which can be detected in most cases [2-4].

Mycosis fungoides (MF) and Sézary syndrome (SS) together represent approximately $65 \%$ of all pCTCL cases [3]. MF, which is classified as an indolent non-Hodgkin's lymphoma, occurs mainly in men (62\%) and usually in middle age or later [5]. Commonly, patients with early-stage MF present with pruritic patches and plaques, whereas patients with advanced-stage MF present with cutaneous tumors or erythroderma. SS is a leukemic variant of MF characterized by generalized cutaneous, lymph node, and blood involvement [3]. The International Society for Cutaneous Lymphomas and the Cutaneous Lymphoma Task Force of the European Organisation for Research and Treatment of Cancer (EORTC-CLTF) revised the staging system for pCTCLs in 2007 to incorporate recent advances in diagnostic techniques and tumor cell biology and to standardize evaluation and management across treatment centers $[4,6]$. Most patients present with early-stage disease and thus have a good prognosis and can be optimistic for long-term survival $[5,7]$. The most common causes of pCLCT-related death are immunosuppression and opportunistic infections [2]. Radiotherapy (RT) is the most effective single modality treatment for MF [8]. The duration of cutaneous remission following total skin electron beam therapy (TSEBT) may be influenced by the delivered RT dose, boost radiation, maintenance treatment, radiation tolerability, and disease stage $[9,10]$.

\section{KARGER}

() 2017 S. Karger GmbH, Freiburg 


\section{Current Therapeutic Options for pCTCL}

Recently published national and international treatment guidelines are used to inform treatment selection on the basis of patients' clinical condition and tumor stage [7, 11-14]. Many topical and systemic therapies have been developed in recent decades. The most commonly used skin-directed therapies are topical steroids, psoralen plus ultraviolet A (PUVA), ultraviolet B, mechlorethamine (a.k.a. nitrogen mustard), carmustine, topical retinoid, and RT. Systemic therapies include oral retinoid, single or multiagent chemotherapy, steroids, interferon (IFN), extracorporeal photopheresis (ECP), and histone deacetylase (HDAC) inhibitors [7, 11, 15-17]. Combinations of topical and systemic modalities have been explored [16]. In addition, some novel agents and immunotherapies have been reported to have efficacy for the treatment of advanced MF and SS [11, 16, 18, 19]. Finally, allogeneic hematopoietic stem cell transplantation (AHSCT) has emerged as a feasible modality in patients with advanced PCTCL [20, 21].

RT was first employed by Scholtz to treat MF in the early 1900s [22], and TSEBT has been used to treat CTCL since 1951 [23-25]. TSEBT, which capitalizes on the radiation sensitivity of MF, has been well studied, though it remains a very specialized treatment that is not widely available. Palliative low-dose RT has yielded favorable results, even with doses $\leq 10 \mathrm{~Gy}$, with an overall response rate of approximately $90 \%$ [8, 25-27]. Because relapses occurred following low-dose RT, the radiation doses used have been gradually increased up to $36 \mathrm{~Gy}$ to obtain a longer-term clinical benefit; however, this more intensive regimen has been associated with significant treatment-related skin toxicities and late relapses $[8,28]$. Low-dose TSEBT regimens, alone or in combination with other treatments, have been gaining interest recently with the hope of minimizing the risk of adverse events (AEs) and the possibility for repetition in the event of relapse $[8,9,29-31]$. Pre- or post-TSEBT local RT for tumorous lesions, enlarged lymph nodes, and underdosed sites has been recommended to minimize the risk of local relapse [13].

The aim of this review is to highlight the place of TSEBT in the framework of current recommendations and to present promising therapeutic approaches for different forms of pCTCLs (table 1).

\section{MF}

According to current treatment guidelines, treatment options for MF include skin-directed therapies or local RT and TSEBT (table 2). Most patients with early-stage MF can be treated primarily with skin-directed therapy. There are no randomized trials supporting selection of radiation-based therapies over other therapies [16].

In early-stage (T1, T2) disease, ultraviolet B phototherapy and PUVA therapy result in complete response rates (CRRs) of 81 and $71 \%$, respectively [32]. Adjuvant IFN or retinoids following PUVA may be more effective and tend to prolong relapse-free survival (RFS) $[16,33,34]$. Topical corticosteroids achieve CRRs of only $63 \%$ in $\mathrm{T} 1$ stage and $25 \%$ in $\mathrm{T} 2$ stage, with most of the responsive patients developing early relapses [35]. Although chemotherapeu- tic mechlorethamine has been found to have good efficacy, it is not widely available outside the US [16].

In refractory early-stage and advanced-stage disease, systemic approaches are mandatory [16]. Commonly, immunomodulatory therapies (i.e. ECP, IFN, retinoids) are used. ECP achieves an overall response rate (ORR) of up to $64 \%$ and a CRR approaching $25 \%$ [36]. Retinoids have been used in PCTCL for over 2 decades with an ORR reaching $75 \%$ and minimal CRR $(<32 \%)$. The most common retinoid currently in use is bexarotene, a synthetic retinoid that activates retinoid X receptors selectively, thereby regulating cellular differentiation, proliferation, and apoptosis. Various retinoid combination treatments have been studied, though there has been no evidence of synergistic activity improving response rates [37]. Combined retinoid and IFN treatment has been administered safely in pCTCL [38]. Low-dose methotrexate, with or without IFN, can be effective for patients with refractory early-stage disease [16].

In terms of novel agents, the proteasome inhibitor bortezomib was reported to result in an ORR of $70 \%$ and a CRR reaching $17 \%[18,79]$. The ORRs associated with pralatrexate and forodesine were in the range of $43-55 \%$, with CRRs not exceeding 22\% [18]. Human recombinant interleukin 12 has also been demonstrated to produce shortterm partial remission (progression-free survival (PFS) 2 months) in $43 \%$ of patients with early-stage MF [39], while a combination of bexarotene and denileukin diftitox has been advanced as a reasonable option for patients with advanced disease [2]. Minimal efficacy of HDAC inhibitors, such as virinostat or romidepsin, and immunomodulatory agents, such as lenalidomide, for pCTCL has been shown (ORRs of approximately 35\%) [18]. Other HDAC inhibitors currently being investigated include entinostat, belinostat, panobinostat, AN-7, and quisinostat [2]. In situ vaccination against MF by intratumoral injection of a Toll-like receptor agonist combined with ultralow-dose local RT (4 Gy) seems to be feasible (ORR 35\%) with acceptable toxicities [19].

\section{TSEBT Technique}

The 'six-dual-field' or modified Standford technique is commonly used to deliver TSEBT $[24,40]$. During irradiation, patients stand in an upright position on a static base. The rotational TSEB technique has also been successfully used in some studies [10, 41]. Electron beams with 6-9 $\mathrm{MeV}$ are usually used (depending on the depth of skin infiltration) to treat 3 anterior and 3 posterior treatment fields, each having a superior and inferior portal with beam angulations. The radiation treatment typically takes $20-30 \mathrm{~min}$ per day. Supplementary radiation to the medial thigh, plantar surfaces, perineal, scalp, and other areas may be planned to compensate for underdosing in these regions based on thermoluminescent dosimeter measurements or according to clinical findings.

\section{TSEBT Results}

Among tested PCTCL treatment modalities, RT has achieved the highest ORR (Table 2). In a retrospective study by Kim et al. [43], 


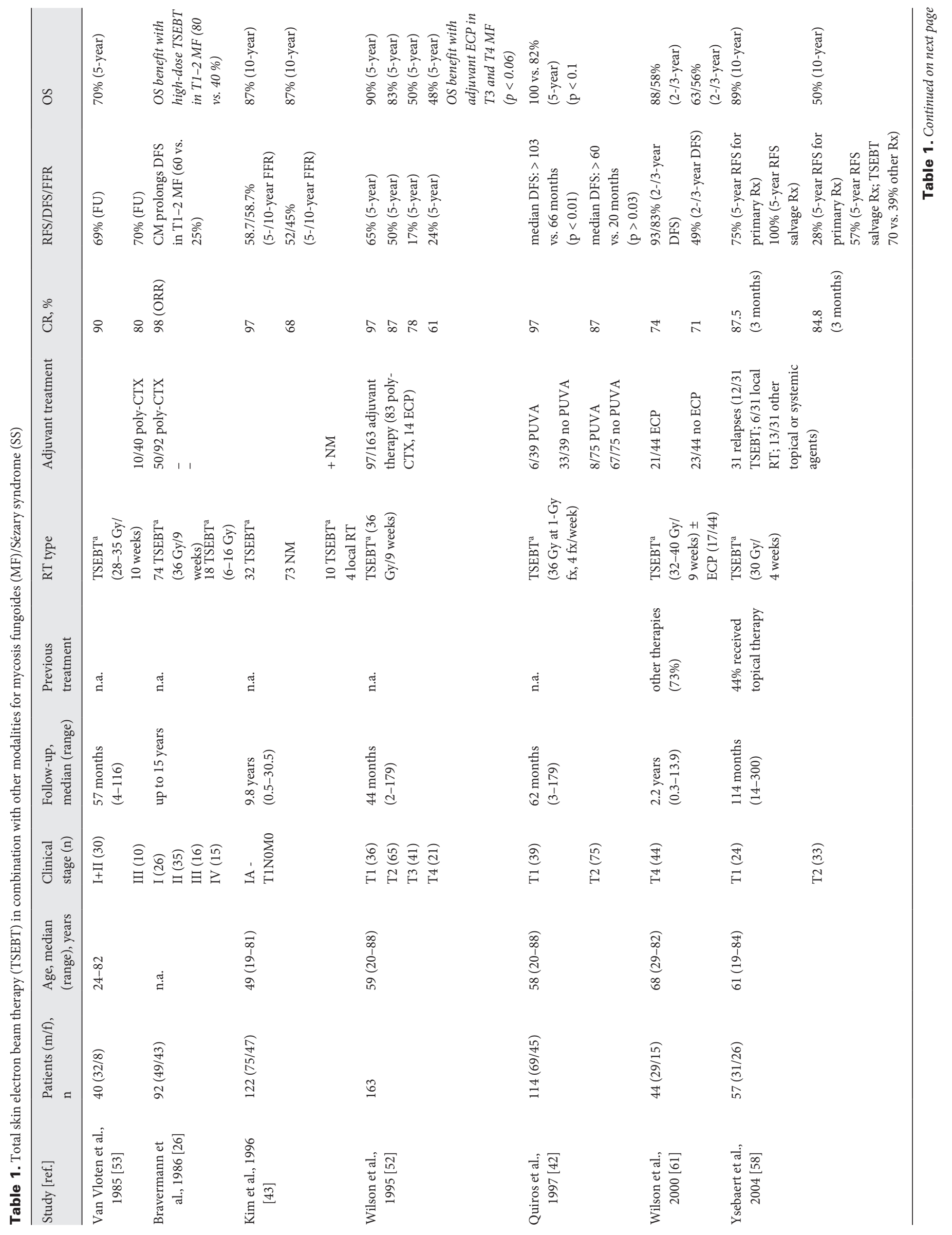




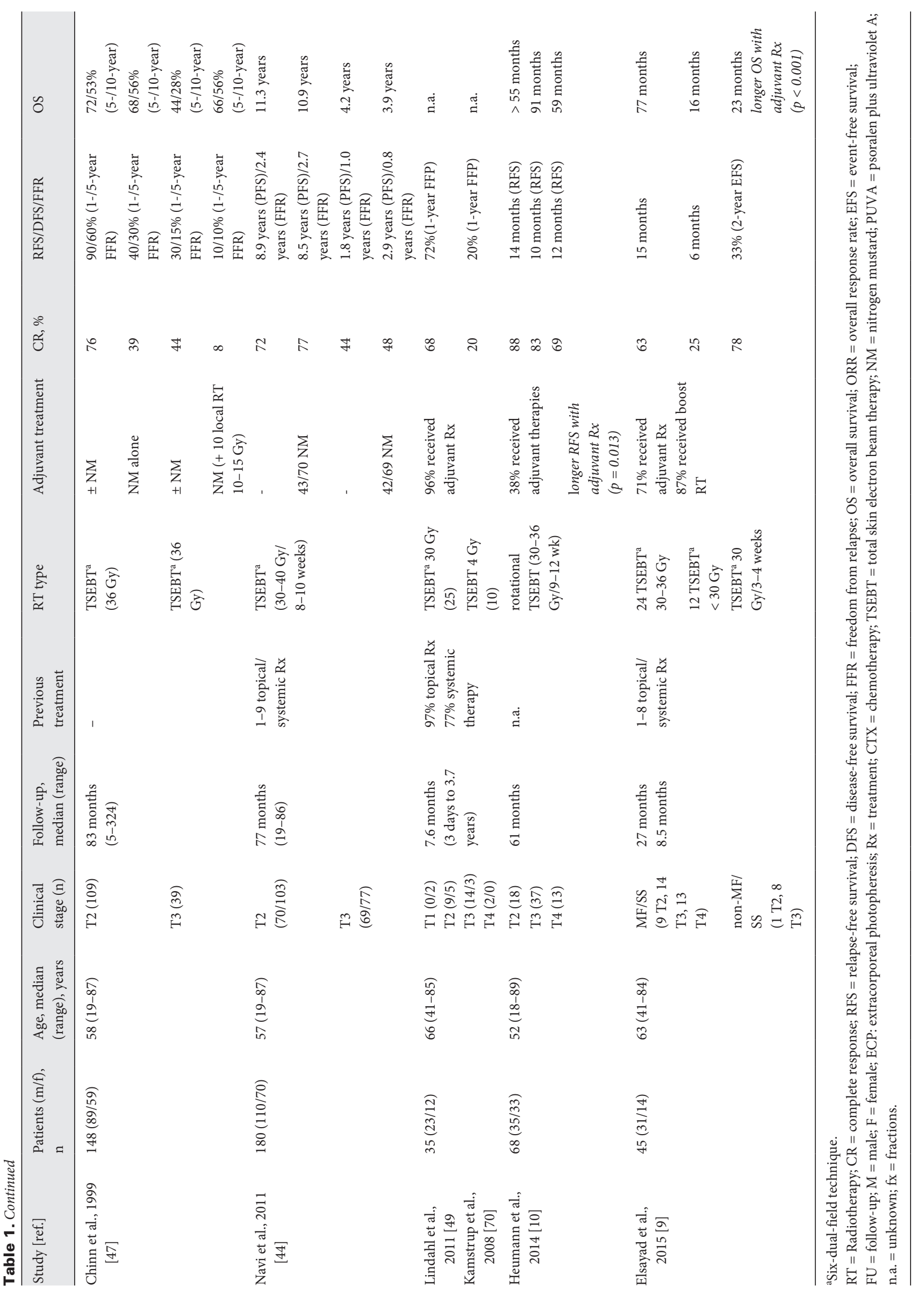


Table 2. Efficacy and toxicity rate of different treatments for mycosis fungoides/Sézary syndrome

\begin{tabular}{|c|c|c|c|c|c|}
\hline Therapy [ref.] & Disease stage & $\begin{array}{l}\text { ORR, median } \\
\text { (range), \% }\end{array}$ & $\mathrm{CR}, \%$ & $\begin{array}{l}\text { Toxicities } \\
\text { (grades 3/4), \% }\end{array}$ & Duration of responses or TTNT \\
\hline Local radiotherapy [71] & $\mathrm{T} 1$ & 100 & 97 & none & 10-year: $85 \%$ \\
\hline Topical steroids [35] & $\mathrm{T} 1-2$ & $90(82-94)$ & $49(25-63)$ & none & $\begin{array}{l}6 \% \text { relapse rate after median follow-up } \\
\text { of } 9 \text { months (range } 3-36 \text { ) }\end{array}$ \\
\hline PUVA and ultraviolet B $[32,72,73]$ & $\mathrm{T} 1-2$ & $74-100$ & $22-81$ & none & median 10-24 months (range $1-66$ ) \\
\hline Human recombinant interleukin 12 [39] & $\mathrm{T} 1-2$ & 43 & 0 & 13 & median 2 months \\
\hline Mechlorethamine [74] & $\mathrm{T} 1-4$ & 83 & 50 & rare & median 12 months \\
\hline Oral retinoid $[37,75]$ & $\mathrm{T} 1-4$ & $54-75$ & $8-31$ & rare & median $7-16$ months (range 1 to $>48$ ) \\
\hline Chemotherapies [55] & $\mathrm{T} 1-4$ & $25-80$ & $11-22$ & common & median 4 months (range 2-6) \\
\hline TSEB (low or high dose) $[29,44,59]$ & $\mathrm{T} 2-4$ & $95^{\mathrm{a}}$ & $29-75^{\mathrm{a}}$ & $0-10^{\mathrm{a}}$ & median 6-29 months ${ }^{\mathrm{a}}$ \\
\hline $\mathrm{ECP}[36,55]$ & $\mathrm{T} 2-4$ & $56(32-62)$ & $18(9-28)$ & rare & median 9 months (6-13); 1-year: $39 \%$ \\
\hline $\begin{array}{l}\text { HDACi (i.e., vorinostat, romidepsin) } \\
\qquad[55,76,77]\end{array}$ & $\mathrm{T} 2-4$ & $30-34$ & $1.3-6$ & 6 & range $4.5-8$ months \\
\hline Toll-like receptor agonist [19] & $\mathrm{T} 2-4$ & 36 & 0 & 7 & range $6-37$ months \\
\hline \multicolumn{6}{|l|}{ Immunotherapies $[55,63-66,78]$} \\
\hline Brentuximab & $\mathrm{T} 2-4$ & $54-73$ & $\leq 35$ & $6-31$ & median 13 months \\
\hline Mogamulizumab & $\mathrm{T} 2-4$ & 37 & 8 & $24-73$ & median 11 months \\
\hline Zanolimumab & $\mathrm{T} 2-4$ & 56 & 9 & 4 & median 20 months \\
\hline Alemtuzumab & $\mathrm{T} 2-4$ & 51 & 18 & 62 & median 3-4 months \\
\hline Bortezomib [79] & T3-4 & 67 & 17 & 17 & range $7-14$ months \\
\hline
\end{tabular}

aSeverity and adverse event rate vary according to radiation dose delivered.

ORR = Overall response rate; $\mathrm{CR}=$ complete response; TTNT = time to next treatment; PUVA = psoralen plus ultraviolet $\mathrm{A}$; TSEB = total-skin electron beam therapy; ECP = extracorporeal photopheresis; $\mathrm{HDACi}=$ histone deacetylase inhibitor.

TSEBT lead to a CRR of $97 \%$ in patients with stage T1 disease, compared to $68 \%$ for mechlorethamine, with a higher RFS (10-year RFS rates 59 versus $45 \%$, respectively; $\mathrm{p}<0.05)$. However, this efficacy did not translate into a long-term survival benefit (10-year overall survival (OS), 87 and $87 \% ; \mathrm{p}=0.2$ ). In addition, TSEBT is a reasonable treatment option for patients with $\mathrm{T} 2$ and $\mathrm{T} 3$ disease owing to its penetration ability, which seems to be superior to that of mechlorethamine $[44,45]$. TSEBT for T4 disease or SS remains controversial. However, cutaneous and peripheral blood improvement has been reported in 82 and $55 \%$ of patient groups, respectively. These findings indicate that antitumor immunity can be restored in addition to reducing tumor burden to minimal levels before AHSCT [46].

In terms of multimodal therapeutic approaches, delivery of neoadjuvant, concurrent, or adjuvant therapy with TSEB remains controversial due to an inconsistency of findings across different treatment centers. Several studies (table 1) reported significant improvements in CRR, disease-free survival (DFS), and OS benefits following multimodal approaches. In patients with early MF (T1, T2), adjuvant PUVA therapy improved 5-year DFS significantly in comparison to non-PUVA adjuvant/no adjuvant therapy (85 vs. $50 \% ; \mathrm{p}<0.02$ ) [42]. Superiority of TSEBT with 8-36 Gy \pm mechlorethamine for 16 months over mechlorethamine alone has been observed in T2 (CRR, 76 vs. 39\%; $\mathrm{p}=0.03$ ) and T3 disease (CRR, 44 vs. $8 \%$; $\mathrm{p}<0.05$ ), with longer RFS in patients who received adjuvant mechlorethamine therapy [47]. Similarly, Price et al. [48] reported a modest improvement with adjuvant mechlorethamine (37 vs. 29 months without mechlorethamine). However, no clinical advantage of adjuvant mechlorethamine (for 6 months) in com- plete responders to TSEBT was observed after longer follow-up in $\mathrm{T} 2$ and T3 disease, perhaps due to the short duration of adjuvant mechlorethamine or the limited number of prior treatments [44]. Regarding previous therapies, a tendency to sustain TSEBT effectiveness in patients treated previously with mechlorethamine has been observed [49]. Combined TSEBT and IFN (for 1 year) is a feasible option, with increased but acceptable acute toxicity, though the addition of IFN did not improve outcome per se [50]. In contrast, a combination of conventional-dose TSEBT with concurrent oral retinoids has shown an acceptable toxicity profile without compromising either therapy $[38,51]$.

Single or multi-agent chemotherapy (i.e., methotrexate, liposomal doxorubicin, gemcitabine, pentostatin, chlorambucil, cyclophosphamide, vincristine, prednisone, or etoposide) can be considered in patients with extracutaneous involvement and results in CRRs ranging from 11 to $57 \%$, while combined conventional-dose TSEBT (24-40 Gy) with chemotherapy can yield higher CRRs (23$88 \%)[17,38]$ with a trend towards a survival gain $[26,52,53]$. In a randomized trial [54], TSEBT with 30 Gy combined with polychemotherapy was compared with topical therapy in 103 patients with MF. Although the combined therapy had a significantly higher CRR ( 38 vs. $18 \%$; $\mathrm{p}=0.032$ ), DFS and OS were identical in the 2 groups [54]. Duvic et al. [38] analyzed the effectiveness of a multimodal approach including induction and maintenance therapies applied in sequence with TSEBT in $28 \mathrm{MF} / \mathrm{SS}$ patients. Among early-stage patients, the CRR was $94 \%$ (median RFS 18 months), whereas in stage III-IV patients, the CR was $64 \%$ (median RFS 5 months) [38]. Generally, combined modalities are well tolerated. 

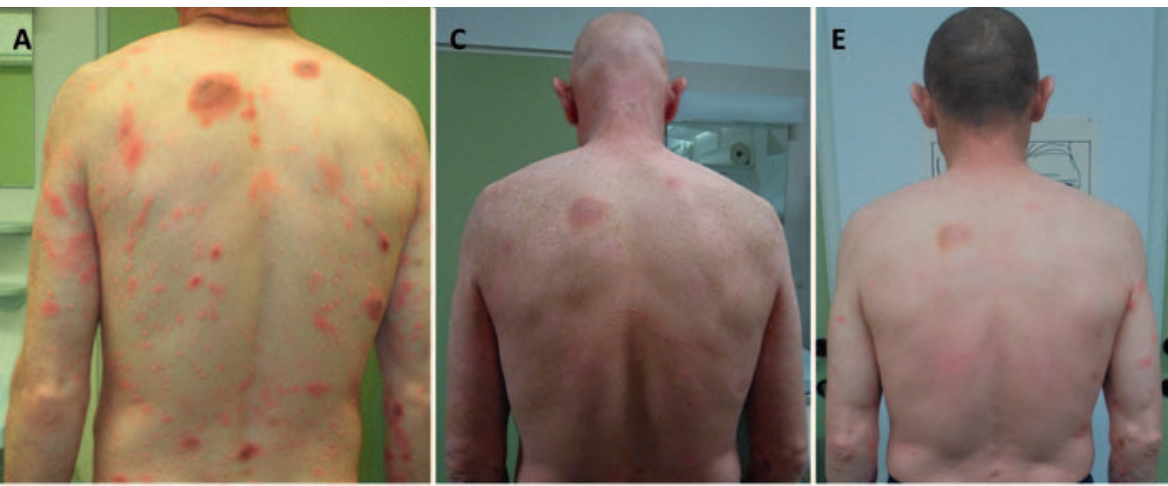

Fig. 1. Lesions in a patient with primary cutane ous aggressive CD8+ T-cell lymphoma. A, B Appearance before with mSWAT score of 116. C, D 6 weeks following total skin electron beam therapy (TSEBT; total dose of 24 Gy administered with 1 Gy daily fractions in 5 weeks) demonstrating complete remission of skin manifestations with grade $1 / 2$ adverse events (hair loss and skin dryness).

E, F 6 months following TSEBT showing localized skin relapses (mSWAT of 12); note hair growth and resolution of skin adverse events.
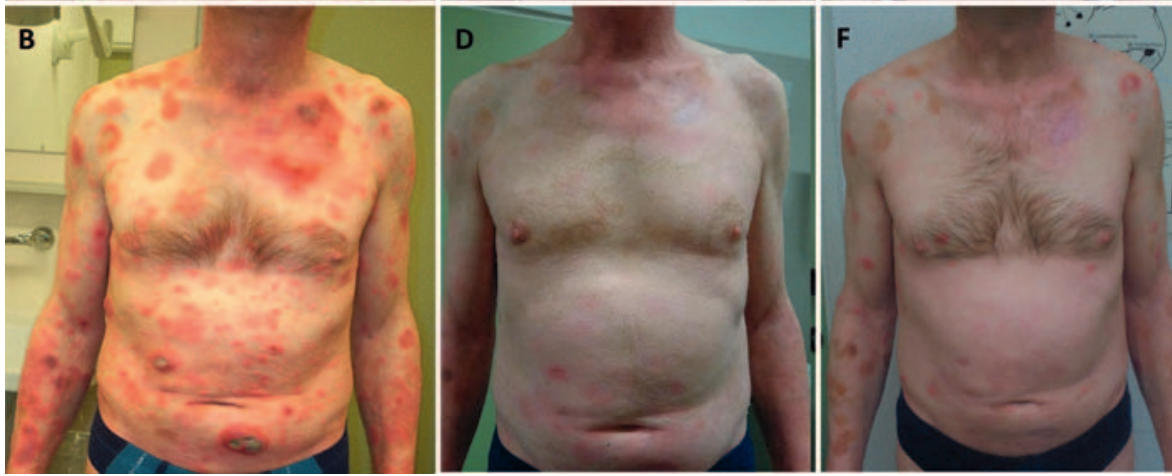

However, serious toxicities during intensive chemotherapy regimens have been reported $[38,54]$. In a recent study by Hughes et al. [55], chemotherapy appeared to have a limited durability of disease control when compared with other therapies. The most recent consensus recommendations from EORTC-CLTF consider maintenance topical (i.e., cortisone, PUVA, UVB, mechlorethamine) or systemic therapies (i.e., low-dose methotrexate, IFN, retinoids, ECP) for MF/SS patients to improve/sustain the duration of clinical benefit [14].

In general, $30 \mathrm{~Gy}$ is considered for advanced disease, high percentage of tumors, or in the definitive setting prior to transplant. However, low-dose TSEBT ( $<30 \mathrm{~Gy}$ ) has been used to palliate skin manifestations of MF/SS with a reasonable remission rate $[25,56]$. In a recent prospective phase II trial $[29,30]$ evaluating the efficacy of low-dose TSEBT with 10-12 Gy in MF (stage IB-IV), an 8-week median time to clinical response was observed. The ORRs were in the range of $88-95 \%$, with a CRR of approximately $30 \%[29,30]$. Improvement in pruritus occurred in approximately $60 \%$ of the patients [29]. In addition, a reduction in disease burden may improve the ability to control any remaining disease with topical therapies [30]. Regarding the RFS, no significant difference between low-dose and conventional dose regimens could be detected $[8,9]$. In a study conducted at the Stanford Cancer Center, Harrison et al. [8] found a similar ORR (approximately 98\%) and CRR (approximately $35 \%$ ) in patients treated with low-dose (10 to < $20 \mathrm{~Gy})$ and medium-dose $(20$ to $<30 \mathrm{~Gy})$ regimens [8]. An ultralow radiation dose (4 Gy/4 days), however, yielded a CRR $(\mathrm{p}<0.01)$ and freedom from progression rate $(\mathrm{p}<0.01)$ significantly less than those obtained with conventional-dose regimens [49].

TSEBT followed by AHSCT may represent a feasible treatment with long-term remissions in selected patients with advanced
pCTCL $[20,21]$. In the case of skin relapse, salvage therapy with low-dose radiation-based therapies (local RT or TSEBT) can be conducted safely with a high ORR (90-100\%) [44, 57, 58]. Other skin-directed or systemic salvage treatments have also been applied without loss of efficacy following TSEBT [8, 42, 43, 47]. Ysebaert et al. [58] found that salvage RT showed a DFS of $73 \%$, while other salvage therapies had a DFS of $60 \%$; however, this difference was not significant $(\mathrm{p}=0.3)$.

\section{TSEBT Toxicity}

The most common AEs include fatigue, skin reaction, alopecia, nail ridging or loss, lower leg edema, xerosis, and ocular irritation. In our experience, all patients treated at the University Hospital of Munster report mild skin reactions, with a lower rate of grade 2 and grade 3 toxicities being observed with low-dose regimens $(<30$ Gy) compared to standard-dose regiments; these are almost always temporary (fig. 1). In addition, lower rates of skin infections have been reported with low-dose regimens [30,59]. Table 2 presents an overview of efficacy and toxicity rates of different treatment modalities for MF/SS in comparison with TSEBT.

\section{Variants and Subtypes of MF}

Although treatment experience is limited and most patients are less responsive to skin-targeted therapies, relative to classical MF, RT may be recommended $[3,9,30]$. Surgical excision, topical mechlorethamine, or topical steroids may be an alternative in some patients with granulomatous slack skin or pagetoid reticulosis [3]. 
In follicutropic MF, Van Doorn et al. [60] found that TSEBT achieved higher CRR than PUVA (54 vs. 5\%). However, the duration of remission was quite short, which may be controlled effectively by a maintenance therapy [60]. In addition, low-dose TSEBT (12 Gy) seems to be effective for patients with follicutropic MF (ORR 87\%, CRR 37\%) and large cell transformation (ORR 100\%, CRR 25\%) [30].

\section{Erythrodermic MF and SS}

ECP, with or without IFN-alpha, has been reported to be an effective treatment for erythrodermic MF and SS, with ORRs of up to 90\% (CRR approximately 25\%). Beneficial results with IFN (with or without PUVA) in combination with low-dose chlorambucil and prednisone or with methotrexate, retinoids, and alemtuzumab (an anti-CD52 monoclonal antibody) have also reported [3, 17, 34, $36,61]$. TSEBT as part of a therapeutic regimen seems to be effective in erythrodermic MF and SS; however, few patients sustain long-term cutaneous remission [9, 29, 38, 49, 52, 61, 62]. TSEBT also has a beneficial systemic effect in terms of reducing tumor burden in the peripheral blood in SS patients [46]. A combination of TSEBT and ECP (for 6 months) resulted in a CRR of 74\% in patients with erythrodermic MF, with a significant improvement in DFS and cause-specific survival [61]. In SS, combined immunomodulatory therapy, targeted biologic agents, or TSEBT followed by AHSCT represent promising options with 4-year PFS rates reaching $52 \%[20,21]$.

\section{Non-MF/SS}

Due to the rarity and heterogeneity of non-MF/SS-type pCTCL, there are no established classification or standard treatment recommendations for these patients. Owing to the aggressiveness of most histologic entities of non-MF/SS, most affected patients require chemotherapy as their initial treatment [3]. For solitary or localized lesions, RT or surgical excision can be applied [3]. Patients with extracutaneous disease or rapidly progressive skin disease require systemic chemotherapy (doxorubicin-based multiagent chemotherapy) with or without HSCT [3]. Studies exploring RT use for other forms of pCTCL are lacking; therefore, RT options should be decided individually based on multidisciplinary discussions. In this context, TSEBT has been used effectively in patients with refractory multifocal skin lesions $[9,49]$.

\section{Future Perspective}

Modern immunotherapeutic approaches (i.e., monoclonal antibodies, transimmunization, and customized vaccines) have been explored [19]. Our understanding of pCTCLs is evolving as ongoing research continues to improve our comprehension of the molecular mechanisms underlying malignancy. Such research may enable the development of effective targeted treatment approaches for defined subgroups of patients.

Regarding immunotherapies, the anti-CD52 monoclonal antibody alemtuzumab has been demonstrated to have efficacy in patients with pCTCL (ORR 51\%, CRR 18\%) [18, 78]. A recent phase II clinical trial showed moderate efficacy of the anti-CD30 monoclonal antibody brentuximab vedotin, the anti-CCR4 antibody mogamulizumab, and the anti-CD4 antibody zanolimumab in pCTCLs as monotherapies, with ORRs reaching 73\% (median PFS 13 months), 37\% (median PFS 11 months), and 56\% (median PFS 20 months), respectively [63-66]. In comparison to standard-ofcare options (methotrexate or bexarotene), brentuximab vedotin provides a higher ORR (56 vs. 13\%; p < 0.001) and PFS (16.7 vs. 3.5 months; $\mathrm{p}<0.001$ ) in CD30-expressing pCTCL [67]. A clinical investigation of the new anti-PD1 antibody nivolumab showed that the agent had good tolerability in patients with recurrent or refractory MF with an ORR of $15 \%$ [68]. Preliminary phase I results with the novel targeted immune therapy IPH4102 (an anti-KIR3DL2 monoclonal antibody) showed excellent tolerability in advanced pCTCL patients [69]. Additional studies of these modern immunotherapy approaches in PCTCL are ongoing.

Despite the minimal toxicity profiles of low-dose TSEBT and immunotherapy for MF/SS, combined approaches to enhance RT efficacy or prolong duration of remission/clinical benefit do not yet exist. There are ongoing clinical studies evaluating the toxicity and efficacy of brentuximab combined with 12 Gy TSEBT (phase I trial, ClinicalTrials.gov NCT02822586) and analyzing the toxicity profile of recombinant interleukin-12 combined with 12 Gy TSEBT (phase II trial, ClinicalTrials.gov NCT02542124). Additionally, another phase II study of low-dose TSEBT combined with 12 Gy with or without 1 year of weekly maintenance therapy with mechlorethamine gel was registered recently (ClinicalTrials.gov NCT02881749).

\section{Conclusion}

Due to the rarity of PCTCL, randomized clinical trials comparing different treatment modalities are lacking. TSEBT has been found to be an efficacious treatment modality for several forms of pCTCL at several radiation doses and can be recommended for curative or palliative intent. In addition, TSEBT may be administered to patients at any time point after diagnosis of MF. That being said, patients requiring rapid relief from cutaneous lesions or symptoms particularly benefit from TSEBT as an initial therapy.

Treatment availability is an important factor in treatment decisions. Combined and/or maintenance therapy administration following TSEBT may prolong the duration of disease remission and warrants further investigation. Trends are moving towards shortcourse low-dose TSEBT regimens with, so far, good clinical results. Because of the high efficacy of TSEBT and the highly dynamic field of immunotherapy, specialized academic institutions should collaborate with hospitals in the treatment of pCTCLs to provide access to these therapeutic options and to evaluate the effectiveness of combined approaches in randomized trials. 


\section{Disclosure Statement}

The authors declare no conflict of interest.

\section{References}

1 Bradford PT, Devesa SS, Anderson WF, Toro JR: Cutaneous lymphoma incidence patterns in the United States: a population-based study of 3,884 cases. Blood 2009;113:5064-5073.

2 Bagherani N, Smoller BR: An overview of cutaneous T cell lymphomas. F1000Res 2016;5.

3 Willemze R, Jaffe ES, Burg G, Cerroni L, Berti E, Swerdlow SH, Ralfkiaer E, Chimenti S, Diaz-Perez JL, Duncan LM, Grange F, Harris NL, Kempf W, Kerl H, Kurrer M, Knobler R, Pimpinelli N, Sander C, Santucci M, Sterry W, Vermeer MH, Wechsler J, Whittaker S, Meijer CJ: WHO-EORTC classification for cutaneous lymphomas. Blood 2005;105:3768-3785.

4 Olsen E, Vonderheid E, Pimpinelli N, Willemze R, Kim Y, Knobler R, Zackheim H, Duvic M, Estrach T, Lamberg S, Wood G, Dummer R, Ranki A, Burg G, Heald P, Pittelkow M, Bernengo M-G, Sterry W, Laroche L, Trautinger F, Whittaker S: Revisions to the staging and classification of mycosis fungoides and Sezary syndrome: a proposal of the International Society for Cutaneous Lymphomas (ISCL) and the cutaneous lymphoma task force of the European Organization of Research and Treatment of Cancer (EORTC). Blood 2007;110:1713-1722.

5 Agar NS, Wedgeworth E, Crichton S, Mitchell TJ, Cox M, Ferreira S, Robson A, Calonje E, Stefanato CM Wain EM, Wilkins B, Fields PA, Dean A, Webb K, Scarisbrick J, Morris S, Whittaker SJ: Survival outcomes and prognostic factors in mycosis fungoides/ Sezary syndrome: validation of the revised International Society for Cutaneous Lymphomas/European Organisation for Research and Treatment of Cancer staging proposal. J Clin Oncol 2010;28:4730-4739.

6 Kim YH, Willemze R, Pimpinelli N, Whittaker S, Olsen EA, Ranki A, Dummer R, Hoppe RT: TNM classification system for primary cutaneous lymphomas other than mycosis fungoides and Sezary syndrome: a proposal of the International Society for Cutaneous Lymphomas (ISCL) and the Cutaneous Lymphoma Task Force of the European Organization of Research and Treatment of Cancer (EORTC). Blood 2007;110: 479-484.

7 Jones GW, Kacinski BM, Wilson LD, Willemze R, Spittle M, Hohenberg G, Handl-Zeller L, Trautinger F, Knobler R: Total skin electron radiation in the management of mycosis fungoides: consensus of the European Organization for Research and Treatment of Cancer (EORTC) Cutaneous Lymphoma Project Group. J Am Acad Dermatol 2002;47:364-370.

8 Harrison C, Young J, Navi D, Riaz N, Lingala B, Kim Y, Hoppe R: Revisiting low-dose total skin electron beam therapy in mycosis fungoides. Int J Radiat Oncol Biol Phys 2011;81:e651-e657.

9 Elsayad K, Kriz J, Moustakis C, Scobioala S, Reinartz G, Haverkamp U, Willich N, Weishaupt C, Stadler R, Sunderkotter C, Eich HT: Total skin electron beam for primary cutaneous $\mathrm{T}$-cell lymphoma. Int J Radiat Oncol Biol Phys 2015;93:1077-1086.

10 Heumann TR, Esiashvili N, Parker S, Switchenko JM, Dhabbaan A, Goodman M, Lechowicz MJ, Flowers CR, Khan MK: Total skin electron therapy for cutaneous T-cell lymphoma using a modern dual-field rotational technique. Int J Radiat Oncol Biol Phys 2015;92: 183-191.
11 Willemze R, Hodak E, Zinzani PL, Specht L, Ladetto M: Primary cutaneous lymphomas: ESMO Clinical Practice Guidelines for diagnosis, treatment and follow-up. Ann Oncol 2013;24(suppl 6):vi149-154.

12 Horwitz SM, Zelenetz AD, Gordon LI, Wierda WG, Abramson JS, Advani RH, Andreadis CB, Bartlett N, Byrd JC, Fayad LE, Fisher RI, Glenn MJ, Habermann TM, Harris NL, Hernandez-Ilizaliturri F, Hoppe RT, Kaminski MS, Kelsey CR, Kim YH, Krivacic S, La Casce AS, Lunning M, Nademanee A, Press O, Rabinovitch R, Reddy N, Reid E, Roberts K, Saad AA, Sokol L, Swinnen LJ, Vose JM, Yahalom J, Zafar N, Dwyer M, Sundar H, Porcu P: NCCN guidelines insights: nonhodgkin's lymphomas, version 3.2016. J Natl Compr Canc Netw 2016;14:1067-1079.

13 Specht L, Dabaja B, Illidge T, Wilson LD, Hoppe RT: Modern radiation therapy for primary cutaneous lymphomas: field and dose guidelines from the International Lymphoma Radiation Oncology Group. Int J Radiat Oncol Biol Phys 2015;92:32-39.

14 Trautinger F, Eder J, Assaf C, Bagot M, Cozzio A, Dummer R, Gniadecki R, Klemke C-D, Ortiz-Romero PL, Papadavid E, Pimpinelli N, Quaglino P, Ranki A, Scarisbrick J, Stadler R, Vakeva L, Vermeer MH, Whittaker S, Willemze R, Knobler R: European Organisation for Research and Treatment of Cancer consensus recommendations for the treatment of mycosis fungoides/Sezary syndrome - Update 2017. Eur J Cancer 2017;77:57-74.

15 Horwitz SM, Olsen EA, Duvic M, Porcu P, Kim YH: Review of the treatment of mycosis fungoides and Sézary syndrome: a stage-based approach. J Natl Compr Canc Netw 2008;6:436-442.

16 Whittaker S, Hoppe R, Prince HM: How I treat mycosis fungoides and Sezary syndrome. Blood 2016;127: 3142-3153.

17 Hoppe RT, Wood GS, Abel EA: Mycosis fungoides and the Sézary syndrome: pathology, staging, and treatment. Curr Probl Cancer 1990;14:297-361.

18 Jain S, Zain J, O'Connor O: Novel therapeutic agents for cutaneous T-cell lymphoma. J Hematol Oncol 2012;5:24.

19 Kim YH, Gratzinger D, Harrison C, Brody JD, Czerwinski DK, Ai WZ, Morales A, Abdulla F, Xing L, Navi D, Tibshirani RJ, Advani RH, Lingala B, Shah S, Hoppe RT, Levy R: In situ vaccination against mycosis fungoides by intratumoral injection of a TLR9 agonist combined with radiation: a phase 1/2 study. Blood 2012; 119:355-363.

20 Polansky M, Talpur R, Daulat S, Hosing C, Dabaja B, Duvic M: Long-term complete responses to combination therapies and allogeneic stem cell transplants in patients with Sezary syndrome. Clin Lymphoma Myeloma Leuk 2015;15:e83-93.

21 Hosing C, Bassett R, Dabaja B, Talpur R, Alousi A, Ciurea S, Popat U, Qazilbash M, Shpall EJ, Oki Y, Nieto Y, Pinnix C, Fanale M, Maadani F, Donato M, Champlin R, Duvic M: Allogeneic stem-cell transplantation in patients with cutaneous lymphoma: updated results from a single institution. Ann Oncol 2015;26: 2490-2495.

22 Scholtz W: Ueber den Einfluss der Röntgenstrahlen auf die Haut in gesundem und krankem Zustande. Archiv für Dermatologie und Syphilis 1902;59:421-446.
23 Trump JG, Wright KA, Evans WW, Anson JH, Hare HF, Fromer JL, Jacque G, Horne KW: High energy electrons for the treatment of extensive superficial malignant lesions. Am J Roentgenol Radium Ther Nucl Med 1953;69:623-629.

24 Karzmark CJ, Loevinger R, Steele RE, Weissbluth M: A technique for large-field, superficial electron therapy. Radiology 1960;74:633-644.

25 Lo TC, Salzman FA, Moschella SL, Tolman EL, Wright KA: Whole body surface electron irradiation in the treatment of mycosis fungoides. An evaluation of 200 patients. Radiology 1979;130:453-457.

26 Braverman IM, Yager NB, Chen M, Cadman EC, Hait WN, Maynard T: Combined total body electron beam irradiation and chemotherapy for mycosis fungoides. J Am Acad Dermatol 1987;16:45-60.

27 Dabaja B: Renaissance of low-dose radiotherapy concepts for cutaneous lymphomas. Oncol Res Treat 2017; 40.

28 Hoppe RT, Fuks Z, Bagshaw MA: Radiation therapy in the management of cutaneous T-cell lymphomas. Cancer Treat Rep 1979;63:625-632.

29 Kamstrup MR, Gniadecki R, Iversen L, Skov L, Petersen PM, Loft A, Specht L: Low-dose (10-Gy) total skin electron beam therapy for cutaneous T-cell lymphoma: an open clinical study and pooled data analysis. Int J Radiat Oncol Biol Phys 2015;92:138-143.

30 Hoppe RT, Harrison C, Tavallaee M, Bashey S, Sundram U, Li S, Million L, Dabaja B, Gangar P, Duvic M, Kim YH: Low-dose total skin electron beam therapy as an effective modality to reduce disease burden in patients with mycosis fungoides: results of a pooled analysis from 3 phase-II clinical trials. J Am Acad Dermatol 2015;72:286-292.

31 Elsayad K, Oertel M, Haverkamp U, Eich HT: The effectiveness of radiotherapy for leukemia cutis. J Cancer Res Clin Oncol 2017;143:851-859.

32 Diederen PVMM, van Weelden H, Sanders CJG, Toonstra J, van Vloten WA: Narrowband UVB and psoralen-UVA in the treatment of early-stage mycosis fungoides: a retrospective study. J Am Acad Dermatol 2003;48:215-219.

33 Thomsen K, Hammar H, Molin L, Volden G: Retinoids plus PUVA (RePUVA) and PUVA in mycosis fungoides, plaque stage. A report from the Scandinavian Mycosis Fungoides Group. Acta Derm Venereol 1989;69:536-538.

34 Roenigk HH, JR, Kuzel TM, Skoutelis AP, Springer E, Yu G, Caro W, Gilyon K, Variakojis D, Kaul K, Bunn PA, JR: Photochemotherapy alone or combined with interferon alpha-2a in the treatment of cutaneous Tcell lymphoma. J Invest Dermatol 1990;95:198S-205S.

35 Zackheim HS, Kashani-Sabet M, Amin S: Topical corticosteroids for mycosis fungoides. Experience in 79 patients. Arch Dermatol 1998;134:949-954.

$36 \mathrm{Zic} \mathrm{JA}$ : The treatment of cutaneous T-cell lymphoma with photopheresis. Dermatol Ther 2003;16:337-346.

37 Panchal MR, Scarisbrick JJ: The utility of bexarotene in mycosis fungoides and Sezary syndrome. Onco Targets Ther 2015;8:367-373.

38 Duvic M, Lemak NA, Redman JR, Eifel PJ, Tucker SL, Cabanillas FF, Kurzrock R: Combined modality therapy for cutaneous T-cell lymphoma. J Am Acad Dermatol 1996;34:1022-1029. 
39 Duvic M, Sherman ML, Wood GS, Kuzel TM, Olsen E, Foss F, Laliberte RJ, Ryan JL, Zonno K, Rook AH: A phase II open-label study of recombinant human interleukin-12 in patients with stage IA, IB, or IIA mycosis fungoides. J Am Acad Dermatol 2006;55:807-813.

40 Page V, Gardner A, Karzmark CJ: Patient dosimetry in the electron treatment of large superficial lesions. Radiology 1970;94:635-641

41 Kumar PP, Henschke UK, Nibhanupudy JR: Problems and solutions in achieving uniform dose distribution in superficial total body electron therapy. J Natl Med Assoc 1977;69:645-647.

42 Quirós PA, Jones GW, Kacinski BM, Braverman IM, Heald PW, Edelson RL, Wilson LD: Total skin electron beam therapy followed by adjuvant psoralen/ultraviolet-A light in the management of patients with $\mathrm{T} 1$ and T2 cutaneous T-cell lymphoma (mycosis fungoides). Int J Radiat Oncol Biol Phys 1997;38:1027-1035.

43 Kim YH, Jensen RA, Watanabe GL, Varghese A, Hoppe RT: Clinical stage IA (limited patch and plaque) mycosis fungoides. A long-term outcome analysis. Arch Dermatol 1996;132:1309-1313.

44 Navi D, Riaz N, Levin YS, Sullivan NC, Kim YH, Hoppe RT: The Stanford University experience with conventional-dose, total skin electron-beam therapy in the treatment of generalized patch or plaque (T2) and tumor (T3) mycosis fungoides. Arch Dermatol 2011; 147:561-567.

45 Hamminga B, Noordijk EM, van Vloten WA: Treatment of mycosis fungoides: total-skin electron-beam irradiation vs topical mechlorethamine therapy. Arch Dermatol 1982;118:150-153

46 Klein RS, Dunlop JD, Samimi SS, Morrissey KA, Evans KG, Gardner JM, Introcaso CE, Vittorio CC, Rook AH, Micaily B, Kim EJ: Improvement in peripheral blood disease burden in patients with Sezary syndrome and leukemic mycosis fungoides after total skin electron beam therapy. J Am Acad Dermatol 2013;68: 972-977.

47 Chinn DM, Chow S, Kim YH, Hoppe RT: Total skin electron beam therapy with or without adjuvant topical nitrogen mustard or nitrogen mustard alone as initial treatment of T2 and T3 mycosis fungoides. Int J Radiat Oncol Biol Phys 1999;43:951-958.

48 Price NM, Hoppe RT, Constantine VS, Fuks ZY, Farber EM: The treatment of mycosis fungoides: adjuvant topical mechlorethamine after electron beam therapy. Cancer 1977;40:2851-2853.

49 Lindahl LM, Kamstrup MR, Petersen PM, Wiren J, Fenger-Gron M, Gniadecki R, Iversen L, Specht L: Total skin electron beam therapy for cutaneous T-cell lymphoma: a nationwide cohort study from Denmark. Acta Oncol 2011;50:1199-1205.

50 Roberge D, Muanza T, Blake G, Shustik C, Vuong T, Freeman CR: Does adjuvant alpha-interferon improve outcome when combined with total skin irradiation for mycosis fungoides? Br J Dermatol 2007;156:57-61.

51 Jones G, McLean J, Rosenthal D, Roberts J, Sauder DN: Combined treatment with oral etretinate and electron beam therapy in patients with cutaneous T-cell lymphoma (mycosis fungoides and Sézary syndrome). J Am Acad Dermatol 1992;26:960-967.

52 Wilson LD, Licata AL, Braverman IM, Edelson RL, Heald PW, Feldman AM, Kacinski BM: Systemic chemotherapy and extracorporeal photochemotherapy for T3 and T4 cutaneous T-cell lymphoma patients who have achieved a complete response to total skin electron beam therapy. Int J Radiat Oncol Biol Phys 1995;32:987-995.

53 Van Vloten WA, de Vroome H, Noordijk EM: Total skin electron beam irradiation for cutaneous T-cell lymphoma (mycosis fungoides). Br J Dermatol 1985; 112:697-702.
54 Kaye FJ, Bunn PA, JR, Steinberg SM, Stocker JL, Ihde DC, Fischmann AB, Glatstein EJ, Schechter GP, Phelps RM, Foss FM: A randomized trial comparing combination electron-beam radiation and chemotherapy with topical therapy in the initial treatment of mycosis fungoides. N Engl J Med 1989;321:1784-1790.

55 Hughes CFM, Khot A, McCormack C, Lade S, Westerman DA, Twigger R, Buelens O, Newland K, Tam C, Dickinson M, Ryan G, Ritchie D, Wood C, Prince HM: Lack of durable disease control with chemotherapy for mycosis fungoides and Sezary syndrome: a comparative study of systemic therapy. Blood 2015;125:71-81.

56 Hoppe RT, Fuks Z, Bagshaw MA: The rationale for curative radiotherapy in mycosis fungoides. Int J Radiat Oncol Biol Phys 1977;2:843-851.

57 Becker M, Hoppe RT, Knox SJ: Multiple courses of high-dose total skin electron beam therapy in the management of mycosis fungoides. Int J Radiat Oncol Biol Phys 1995;32:1445-1449.

58 Ysebaert L, Truc G, Dalac S, Lambert D, Petrella T, Barillot I, Naudy S, Horiot J-C, Maingon P: Ultimate results of radiation therapy for T1-T2 mycosis fungoides (including reirradiation). Int J Radiat Oncol Biol Phys 2004;58:1128-1134.

59 Morris SL, McGovern M, Bayne S, Wain M, Child F, Whittaker S: Results of a 5-week schedule of modern total skin electron beam radiation therapy. Int J Radiat Oncol Biol Phys 2013;86:936-941.

60 Van Doorn R, Scheffer E, Willemze R: Follicular mycosis fungoides, a distinct disease entity with or without associated follicular mucinosis. Arch Dermatol 2002;138:191-198.

61 Wilson LD, Jones GW, Kim D, Rosenthal D, Christensen IR, Edelson RL, Heald PW, Kacinski BM: Experience with total skin electron beam therapy in combination with extracorporeal photopheresis in the management of patients with erythrodermic (T4) mycosis fungoides. J Am Acad Dermatol 2000;43:54-60.

62 Jones GW, Rosenthal D, Wilson LD: Total skin electron radiation for patients with erythrodermic cutaneous T-cell lymphoma (mycosis fungoides and the Sézary syndrome). Cancer 1999;85:1985-1995.

63 Duvic M, Tetzlaff MT, Gangar P, Clos AL, Sui D, Talpur R: Results of a phase II trial of brentuximab vedotin for CD30+ cutaneous T-cell lymphoma and lymphomatoid papulosis. J Clin Oncol 2015;33:37593765.

64 Duvic M, Pinter-Brown LC, Foss FM, Sokol L, Jorgensen JL, Challagundla P, Dwyer KM, Zhang X, Kurman MR, Ballerini R, Liu L, Kim YH: Phase 1/2 study of mogamulizumab, a defucosylated anti-CCR4 antibody, in previously treated patients with cutaneous Tcell lymphoma. Blood 2015;125:1883-1889.

65 Ogura M, Ishida T, Hatake K, Taniwaki M, Ando K, Tobinai K, Fujimoto K, Yamamoto K, Miyamoto T, Uike N, Tanimoto M, Tsukasaki K, Ishizawa K, Suzumiya J, Inagaki $\mathrm{H}$, Tamura $\mathrm{K}$, Akinaga S, Tomonaga M, Ueda R: Multicenter phase II study of mogamulizumab (KW-0761), a defucosylated anti-cc chemokine receptor 4 antibody, in patients with relapsed peripheral T-cell lymphoma and cutaneous T-cell lymphoma. J Clin Oncol 2014;32:1157-1163.

66 Kim YH, Duvic M, Obitz E, Gniadecki R, Iversen L, Osterborg A, Whittaker S, Illidge TM, Schwarz T, Kaufmann R, Cooper K, Knudsen KM, Lisby S, Baadsgaard O, Knox SJ: Clinical efficacy of zanolimumab (HuMax-CD4): two phase 2 studies in refractory cutaneous T-cell lymphoma. Blood 2007;109: 4655-4662.

67 Kim YH, Whittaker S, Horwitz SM, et al.: Brentuximab vedotin demonstrates significantly superior clinical outcomes in patients with CD30-expressing cutaneous T cell lymphoma versus physician's choice (methotrexate or bexarotene): the phase 3 Alcanza study. 2016 ASH Annual Meeting;abstr 182.
68 Lesokhin AM, Ansell SM, Armand P, Scott EC, Halwani A, Gutierrez M, Millenson MM, Cohen AD, Schuster SJ, Lebovic D, Dhodapkar M, Avigan D, Chapuy B, Ligon AH, Freeman GJ, Rodig SJ, Cattry D, Zhu L, Grosso JF, Bradley Garelik MB, Shipp MA, Borrello I, Timmerman J: Nivolumab in patients with relapsed or refractory hematologic malignancy: preliminary results of a phase Ib study. J Clin Oncol 2016;34: 2698-2704.

69 Bagot M, Porcu P, Ram-Wolff C, Khodadoust M, Battistella M, Marie-Cardine A, Mathieu S, Vermeer MH, Whittaker S, Duvic M, Bensussan A, Paturel C, Bonnafous C, Thonnart N, Widemann A, Bonin C, Sicard H, Paiva C, Pilz K, Kim Y: First-in-human, multicenter phase I study of IPH4102, first-in-class humanized anti-KIR3DL2 monoclonal antibody, in relapsed/refractory cutaneous T-cell lymphomas: preliminary safety, exploratory and clinical activity results. Blood 2016;128:1826.

70 Kamstrup MR, Specht L, Skovgaard GL, Gniadecki R: A prospective, open-label study of low-dose total skin electron beam therapy in mycosis fungoides. Int J Radiat Oncol Biol Phys 2008;71:1204-1207.

71 Wilson LD, Kacinski BM, Jones GW: Local superficial radiotherapy in the management of minimal stage IA cutaneous T-cell lymphoma (mycosis fungoides). Int J Radiat Oncol Biol Phys 1998;40:109-115.

72 Whittaker S, Ortiz P, Dummer R, Ranki A, Hasan B, Meulemans B, Gellrich S, Knobler R, Stadler R, Karrasch M: Efficacy and safety of bexarotene combined with psoralen-ultraviolet A (PUVA) compared with PUVA treatment alone in stage IB-IIA mycosis fungoides: final results from the EORTC cutaneous lymphoma task force phase III randomized clinical trial (NCT00056056). Br J Dermatol 2012;167:678-687.

73 Ramsay DL, Lish KM, Yalowitz CB, Soter NA: Ultraviolet-B phototherapy for early-stage cutaneous T-cell lymphoma. Arch Dermatol 1992;128:931-933.

74 Kim YH, Martinez G, Varghese A, Hoppe RT: Topical nitrogen mustard in the management of mycosis fungoides: update of the Stanford experience. Arch Dermatol 2003;139:165-173.

75 Duvic M, Martin AG, Kim Y, Olsen E, Wood GS, Crowley CA, Yocum RC: Phase 2 and 3 clinical trial of oral bexarotene (Targretin capsules) for the treatment of refractory or persistent early-stage cutaneous T-cell lymphoma. Arch Dermatol 2001;137:581-593.

76 Whittaker SJ, Demierre MF, Kim EJ, Rook AH, Lerner A, Duvic M, Scarisbrick J, Reddy S, Robak T, Becker JC, Samtsov A, McCulloch W, Kim YH: Final results from a multicenter, international, pivotal study of romidepsin in refractory cutaneous T-cell lymphoma. J Clin Oncol 2010;28:4485-4491.

77 Olsen EA, Kim YH, Kuzel TM, Pacheco TR, Foss FM Parker S, Frankel SR, Chen C, Ricker JL, Arduino JM, Duvic M: Phase IIb multicenter trial of vorinostat in patients with persistent, progressive, or treatment refractory cutaneous T-cell lymphoma. J Clin Oncol 2007;25:3109-3115.

78 De Masson A, Guitera P, Brice P, Moulonguet I, Mouly F, Bouaziz J-D, Battistella M, Madelaine I, Roux J, Ram-Wolff C, Cayuela J-M, Bachelez H, Bensussan A, Michel L, Bagot M: Long-term efficacy and safety of alemtuzumab in advanced primary cutaneous T-cell lymphomas. Br J Dermatol 2014;170:720-724.

79 Zinzani PL, Musuraca G, Tani M, Stefoni V, Marchi E, Fina M, Pellegrini C, Alinari L, Derenzini E, de Vivo A, Sabattini E, Pileri S, Baccarani M: Phase II trial of proteasome inhibitor bortezomib in patients with relapsed or refractory cutaneous T-cell lymphoma. J Clin Oncol 2007;25:4293-4297. 